\title{
A LAKE FORTRESS, A FLOATING CHRONOLOGY, AND AN ATMOSPHERIC ANOMALY: THE SURPRISING RESULTS OF A RADIOCARBON WIGGLE-MATCH FROM ĀRAIŠI, LATVIA
}

\author{
JOHN MEADOWS ${ }^{1,2}$ and MĀRIS ZUNDE ${ }^{3}$ \\ ${ }^{I}$ Leibniz-Labor für Altersbestimmung und Isotopenforschung, Christian-Albrechts-Universität zu Kiel, Germany \\ ${ }^{2}$ Zentrum für Baltische und Skandinavische Archäologie, Stiftung Schleswig-Holsteinische Landesmuseen, \\ Schloss Gottorf, Schleswig, Germany \\ ${ }^{3}$ Dendrochronological Laboratory, Institute of Latvian History at the University of Latvia
}

Received 28 June 2013

Accepted 16 December 2013

\begin{abstract}
An Iron Age timber settlement which, in view of the defensive structures uncovered, is described as a lake fortress, on an island in Lake Äraiši, north-eastern Latvia, was excavated in 1965-69 and 1975-79 by teams led by Jānis Apals, who distinguished five construction phases. Dendrochronological analysis produced a $c$. 100-year floating chronology for Norway spruce (Picea abies (L.) Karst.) timbers from the earliest phase.

$\mathrm{A}{ }^{14} \mathrm{C}$ wiggle-match was undertaken to obtain an absolute date range for the final year of the floating chronology, and thus for the construction of the settlement. Ten blocks of wood from one timber, each comprising 6-11 years and collectively spanning the whole 93 -year tree-ring series, were dated by AMS. Using the IntCal13 calibration data, there is a $95 \%$ probability that the felling date of this timber falls in the range 775-784 cal AD. It appears, however, that the AD 775 spike in the atmospheric ${ }^{14} \mathrm{C}$ level occurred within the 6-year span of the last sample. On this basis, we can narrow the date of construction to 776-780 cal AD. This date is significantly earlier than those reported in previous publications.
\end{abstract}

Keywords: dendrochronology, radiocarbon, wiggle-match, Latvia, AD775 cosmic event.

\section{INTRODUCTION}

Āraiši lake fortress is one of ten such sites in northeastern Latvia, consisting of timber buildings and defensive structures built on a log platform on an island or shoal in a lake (Fig. 1). These sites were discovered by the pioneering Latvian underwater archaeologist Jānis Apals (1930-2011), whose prospection work during the period 1959-1973, in 103 lakes, 15 bogs and some rivers, verified legendary accounts of houses and castles sinking

Corresponding author: J. Meadows

e-mail: jmeadows@leibniz.uni-kiel.de into lakes. Artefacts suggest that these sites date to the second half of the $1^{\text {st }}$ millennium $\mathrm{AD}$.

In 1964 and 1965 a small-scale test excavation was carried out at the Ušuri lake settlement (Apals, 2001; 2012a; 2012b), but the main excavation project took place at Āraiši, where structural remains had already been reported in the 1870s and 80s. In 1965-69 and 1975-79, Apals and his team excavated three-quarters of a c. $2500 \mathrm{~m}^{2}$ cultural layer, most of which lies below the present lake-level, finding remains of 111 wooden houses, outbuildings and 35 defensive structures, built on a foundation of a lattice of $\operatorname{logs}$ covered by a log platform. 


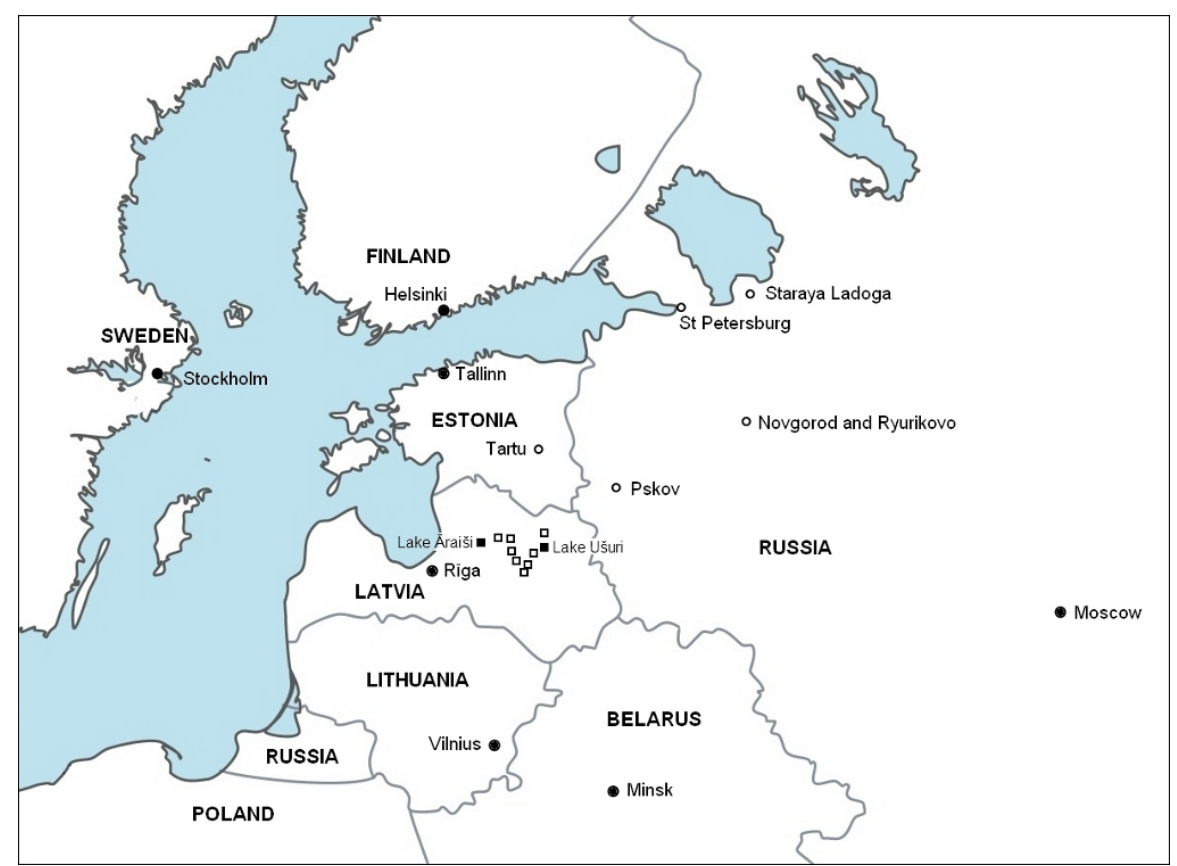

Fig. 1. Location of Āraiši and other sites mentioned in the text (ロ, 口: lake fortress sites discovered in Latvia by J. Apals).

The oldest of the five consecutive building phases, Phase I, had the best-preserved remains (Fig. 2).

\section{EARLIER ATTEMPTS TO DATE THE LAKE FORTRESS}

Many publications and reports on Āraiši over the last 45 years mention that the structures of the earliest building phase were erected in $c$. AD 830 (e.g., Apals, 1983; 1998; 2000; 2001; 2008). Apals appears to have had two timbers ${ }^{14} \mathrm{C}$-dated at Tartu, Estonia, in the $1960 \mathrm{~s}$, from Phase I $(1120 \pm 50 \mathrm{BP}$, reported as "AD 830 ", i.e. subtracting the ${ }^{14} \mathrm{C}$ age from $\left.\mathrm{AD} 1950\right)$ and Phase IV (1060 \pm 60 BP or "AD 890"; TA-156, Punning et al., 1968). Species, intrinsic ages and methods used to pretreat these samples are not recorded. Radiocarbon ages were measured by liquid scintillation counting, using an anthracite standard for background correction, without correcting ${ }^{14} \mathrm{C}$ activity for natural isotopic fractionation $\left(\delta^{13} \mathrm{C}\right)$. The first result was probably communicated directly to Apals, who published it without a laboratory number.

Four "pine" samples said to be from the Āraiši log platform were later ${ }^{14} \mathrm{C}$-dated in St Petersburg (Zaitseva and Popov, 1994). The samples were pretreated with a 2:1 benzene/alcohol solution to remove resin, before conventional acid-alkali-acid extraction and dating by liquid scintillation counting. The samples had apparently been dendro-dated in Moscow in the late 1960s (Chernyh, 1987) and spanned the years AD 835-855 (LE-4225, $1109 \pm 55$ BP), AD 861-865 (LE-4224, $1182 \pm 40$ BP),

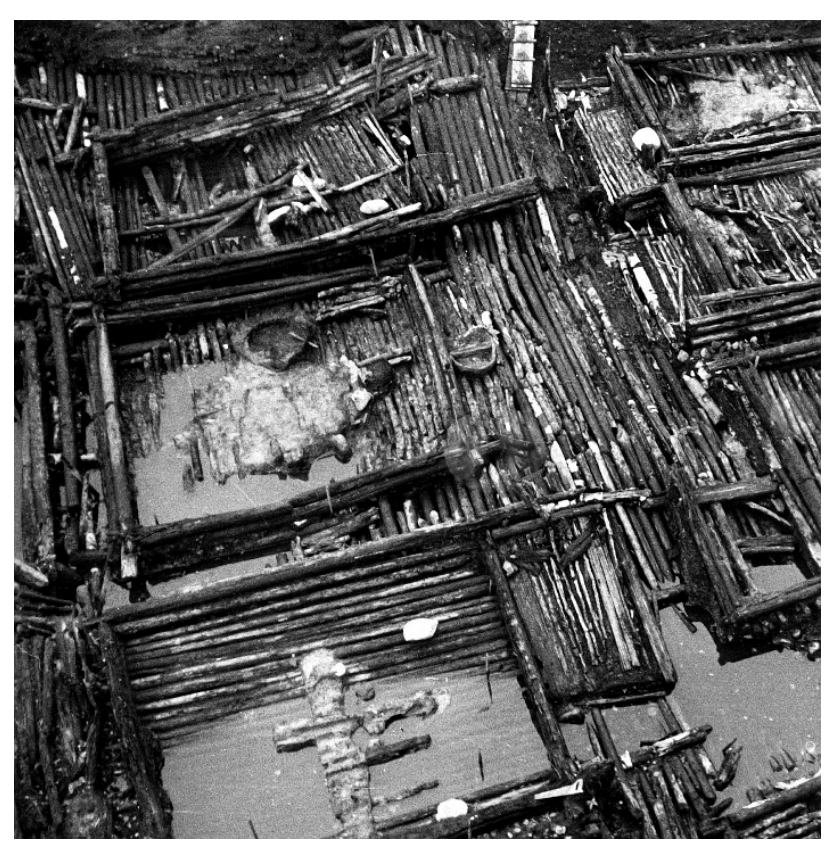

Fig. 2. Part of Phase I of Āraiši lake fortress: remains of the log platform and buildings in the course of excavation (photo: J. Apals).

AD 866-872 (LE-4223, $1210 \pm 60$ BP), and AD 872-876 (LE-4222, $1190 \pm 60$ BP) (Zaitseva and Popov, 1994).

It is unclear whether the St Petersburg ${ }^{14} \mathrm{C}$ samples were all from the same timber, but we assume that their relative dates were determined exactly, either by ringcounting within a single timber, or by dendrochronological cross-matching within a site master chronology. 
Chernyh's (1987) master chronology for Āraiši appears to have been dated by visual cross-matching with previous absolutely-dated chronologies from Novgorod, and subsequently also Ryurikovo and Staraya Ladoga - sites 380-500 km from Āraiši (Fig. 1). According to Zaitseva and Popov (1994), the platform itself was dated dendrochronologically by the Natural Sciences Methods laboratory of the Russian Academy of Science Archaeology Institute, Moscow to AD 920-930, but Chernyh (1996) dated the first structures of the lake fortress to $c$. AD 930, with further buildings built of timbers felled in AD 931, 933, 935, 938, c. 941 and 951 . The calibrated ${ }^{14} \mathrm{C}$ ages from Tartu and St Petersburg are not inconsistent with each other and do not contradict the Moscow dendrodates (Fig. 3).

Several aspects of the Moscow dendrochronological results are perplexing, however. It was unclear whether the timbers had been identified to species, as in the 1960s mixed-conifer site chronologies were frequently built using both Scots pine (Pinus sylvestris L.) and Norway spruce (Picea abies (L.) H. Karst) tree-ring series (Chernyh, 1996). Although the risk of incomplete or absent tree-rings was understood, not all the tree-ring sequences were measured along more than one radius, so it is likely that some tree-ring series included in the site master chronology had missing tree-rings. The tree-ring series were mostly very short, $75 \%$ containing fewer than 50 measurements, and nearly all the rest (37 of 43) having 50-100 rings. Nevertheless, nearly half the tree-ring series measured (73 of 172) were apparently dated, without the use of statistical cross-matching methods. There is even some uncertainty about the date range of the site chronology: both AD 813-989 (177 rings) and AD 783952 (180 rings) were reported (Chernyh, 1996). A second attempt to date the Âraiši structures was made in Latvia in the 1970s; this work was unfinished and unsuccessful, partly because usually only single radii were measured.

\section{DENDROCHRONOLOGY: A NEW FLOATING CHRONOLOGY}

When a dendrochronology laboratory was established at the Institute of Latvian History in the 1990s, a renewed effort was made to dendro-date the Āraiši structures, using new tree-ring measurements along $3-4$ radii in more than 60 surviving wood samples from Āraiši, as well as the previous Moscow and Riga tree-ring measurements, altogether representing 330 building timbers. It was hoped that absolute dates would be obtained for each of the five building phases, and for specific buildings and other structures of the lake fortress.

Cross-matching using the computer programs SAKORE (developed by M. Zunde and G. Jēkabsons), COFECHA (Holmes, 1983; Grissino-Mayer, 2001) and ARSTAN (Cook and Holmes, 1986) showed that the tree-ring series measured previously were often compromised by missing values. Moreover, most timbers came from very young trees: $65 \%$ of samples had less than 50 tree-rings, $24 \%$ had $50-79$ tree-rings and only $11 \%$ had 80 or more tree-rings.

A site master chronology for spruce was developed (Zunde, 2000), consisting mainly of Phase I timbers,

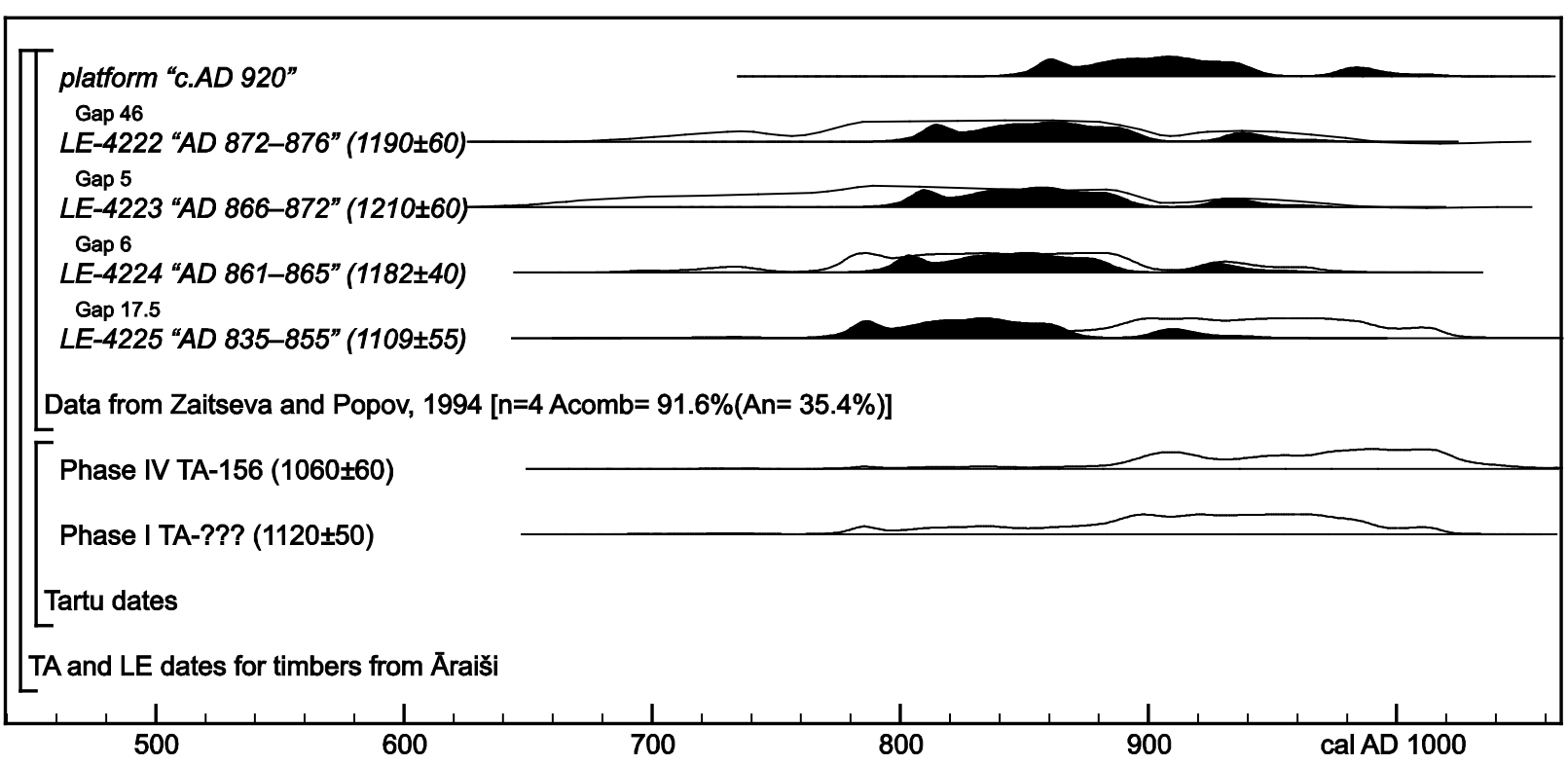

Fig. 3. Calibration and wiggle-matching of earlier ${ }^{14} \mathrm{C}$ results attributed to timbers from Āraiši. Distributions in outline are simple calibrations of the ${ }^{14} \mathrm{C}$ ages, calibrated using the IntCal13 calibration data (Reimer et al., 2013); solid distributions are model estimates of the dates of the St Petersburg samples, based on the calibrated ${ }^{14} \mathrm{C}$ results and calendar age differences between samples according to their dendro-dates, as reported by Zaitseva and Popov (1994). The satisfactory combined agreement index $\left[\mathrm{A}_{\text {comb }}\right]$ shows that the calibrated ${ }^{14} \mathrm{C}$ ages are consistent with the reported age differences between samples. The date of the platform (if 46 years after the midpoint of $L E-4222$ ) is estimated as $840-950$ cal $A D$ (>85\% probability). 
together with some timbers attributed to Phase II or Phase III, although the attribution of single timbers and even buildings to precise phases after Phase I can be ambiguous. The new chronology, which spans about 100 years, includes tree-ring series from 60 timbers; another 19 timbers with slightly more problematic growth patterns can be cross-matched to it (Fig. 4). The floating chronology shows that the log platform and Phase I houses in the centre of the site were built of timbers felled in a single year, while surrounding Phase I buildings were built of timbers felled 1-2 years later. A second site chronology of data from 11 pine timbers can be cross-matched to the spruce master chronology. It is not possible to determine which timber(s) were ${ }^{14} \mathrm{C}$-dated at St. Petersburg, and thus whether those samples can be cross-matched to the new master chronologies.

There is no absolute reference chronology for spruce covering this period in Latvia or elsewhere in the eastern Baltic. There are absolutely-dated pine chronologies from Scandinavia and Poland, but the Āraiši floating chronology is too short for secure long-distance cross-matching. Calibration of the ${ }^{14} \mathrm{C}$ results from Tartu and St Petersburg gives a wide potential date range, even when combined with the relative dating of samples implicit in the Moscow dendro results (Fig. 3: this model dates the platform to 840-950 cal $A D$ [85.5\% probability] or 970$1005 \mathrm{cal} A D[9.9 \%])$. Over such a long time interval, there will often be chance resemblances between a relatively short tree-ring chronology for one site and reference chronologies from other regions, suggesting several potential cross-matching positions. More precise ${ }^{14} \mathrm{C}$ dating of the floating chronology would therefore help to eliminate spurious synchronisations, and to identify valid long-distance cross-matches, if they exist.

\section{RADIOCARBON DATING}

In 2011 we began a joint investigation aimed at more precise absolute dating of Āraiši lake fortress, using the ${ }^{14} \mathrm{C}$ wiggle-matching technique. Simulation models of potential ${ }^{14} \mathrm{C}$ results for the Phase I spruce floating chronology, with expected felling dates in the $9^{\text {th }}-10^{\text {th }}$ centuries, were created using the program OxCal 4.1 (Bronk Ramsey, 2009) and the IntCal09 calibration data (Reimer et al., 2009) (e.g. Fig. 5).

Initially, seven samples from a single timber, ar173, were dated by AMS at the Leibniz-Labor, Kiel (Nadeau et al., 1998; Table 1, KIA-45639-45). The samples each comprised between 6 and 11 tree-rings, altogether spanning the entire 93-year sequence to the bark-edge, but with some hiatuses (Fig. 4). Each sample was pretreated, following an acid-base-acid protocol to remove carbonates and humic acids, and then divided in two. For quality-assurance reasons, both fractions were combusted, graphitised and dated. Weighted means of the paired results were calculated using OxCal's $R_{-}$Combine function (Bronk Ramsey, 1995; Ward and Wilson, 1978), giving typical ${ }^{14} \mathrm{C}$ age uncertainties of \pm 18 or better (Table 1).

OxCal's D_Sequence function (Bronk Ramsey et al., 2001) was then used to fit the weighted mean ${ }^{14} \mathrm{C}$ ages to the IntCa198 (Stuiver et al., 1998) and IntCal09 calibration curves, using the known calendar age differences between samples. Two narrow date ranges for year $n$ (the felling date) were indicated, in the late $8^{\text {th }}$ and early $9^{\text {th }}$ centuries cal AD. A hybrid calibration curve, created using IntCal98 with additional data (McCormac et al., 2004; 2008) subsequently included in the IntCal13 calibration curve (Reimer et al., 2013) provided a better fit at the earlier matching position, but a date in the AD $820 \mathrm{~s}$ was not entirely excluded.

The three samples that were not used initially were therefore dated (Fig. 4, Table 1, KIA-49358-60), as simulation modelling showed that the additional data would allow us to exclude one of the potential date ranges. Wiggle-matching against all three consensus calibration curves indicates that only the $8^{\text {th }}$ century felling date is permitted by the full set of ${ }^{14} \mathrm{C}$ results. Using IntCal13, year $n$ is dated to $775-784$ cal $A D$ (95\% probability) under our preferred model (Fig. 6).

\section{DISCUSSION}

\section{Accuracy of radiocarbon results}

Four of the $20{ }^{14} \mathrm{C}$ measurements were excluded from the wiggle-match model shown in Fig. 6 (both KIA47641 results and both KIA-49360 results). Including them would not significantly alter the wiggle-match date of year $n$, but these results are incompatible with the relative dates of the samples, given the results from the rest of the series. As all the samples are from a single timber, there is no risk of the relative dating being mistaken. ${ }^{1}$

The intervals between samples (Gaps in Fig. 6) are perhaps overly precise, because they assume that the ${ }^{14} \mathrm{C}$ ages date the calendrical midpoint of each sample. In reality, each tree-ring within a multi-year sample will have contributed a different amount of carbon to the measurements, so the calendrical midpoint may not be exactly equivalent to the average ${ }^{14} \mathrm{C}$ age. Moreover, as the pretreated sample material was not homogenized before it was divided, it is possible that the paired ${ }^{14} \mathrm{C}$ results are from material with slightly different calendar ages. Nevertheless, the paired ${ }^{14} \mathrm{C}$ ages are extremely similar in most cases (Table 1).

\footnotetext{
1 It is possible that the midpoints of samples KIA-47645 and KIA-49360 are one year earlier than indicated, relative to the other samples, as cross-matching with the pine/mixed conifer chronology suggests that there may be a missing ring in the first two decades of the sampled timber, ar173. Further work is required to confirm this, but it would not affect cross-matching within the spruce chronology (see Fig. 4) and it would not alter the best wiggle-match position shown in Fig. 6.
} 


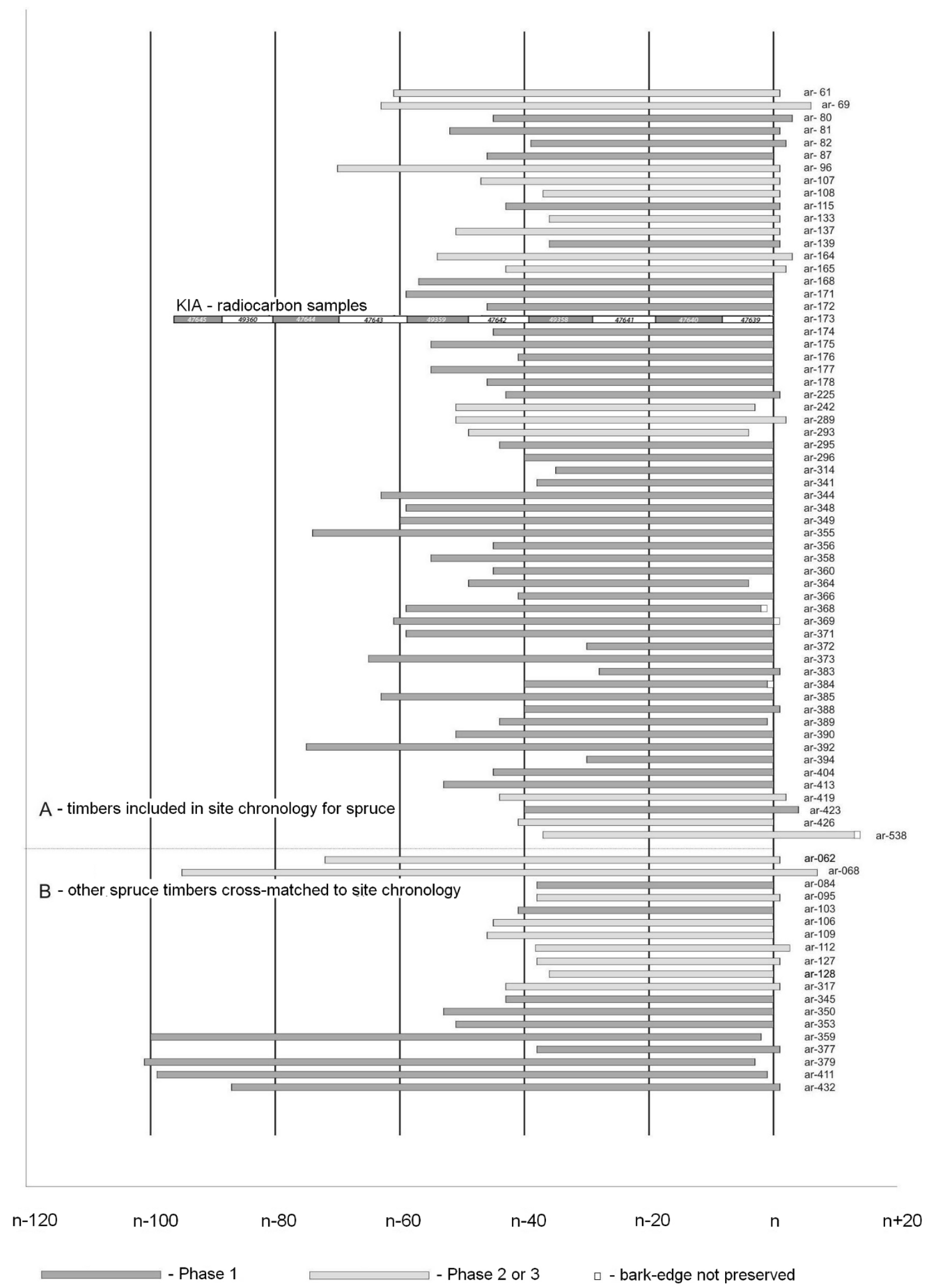

Fig. 4. The main results of relative dendro-dating of structures of Phase I of Āraiši lake fortress, carried out at the Institute of Latvian History at the University of Latvia. 


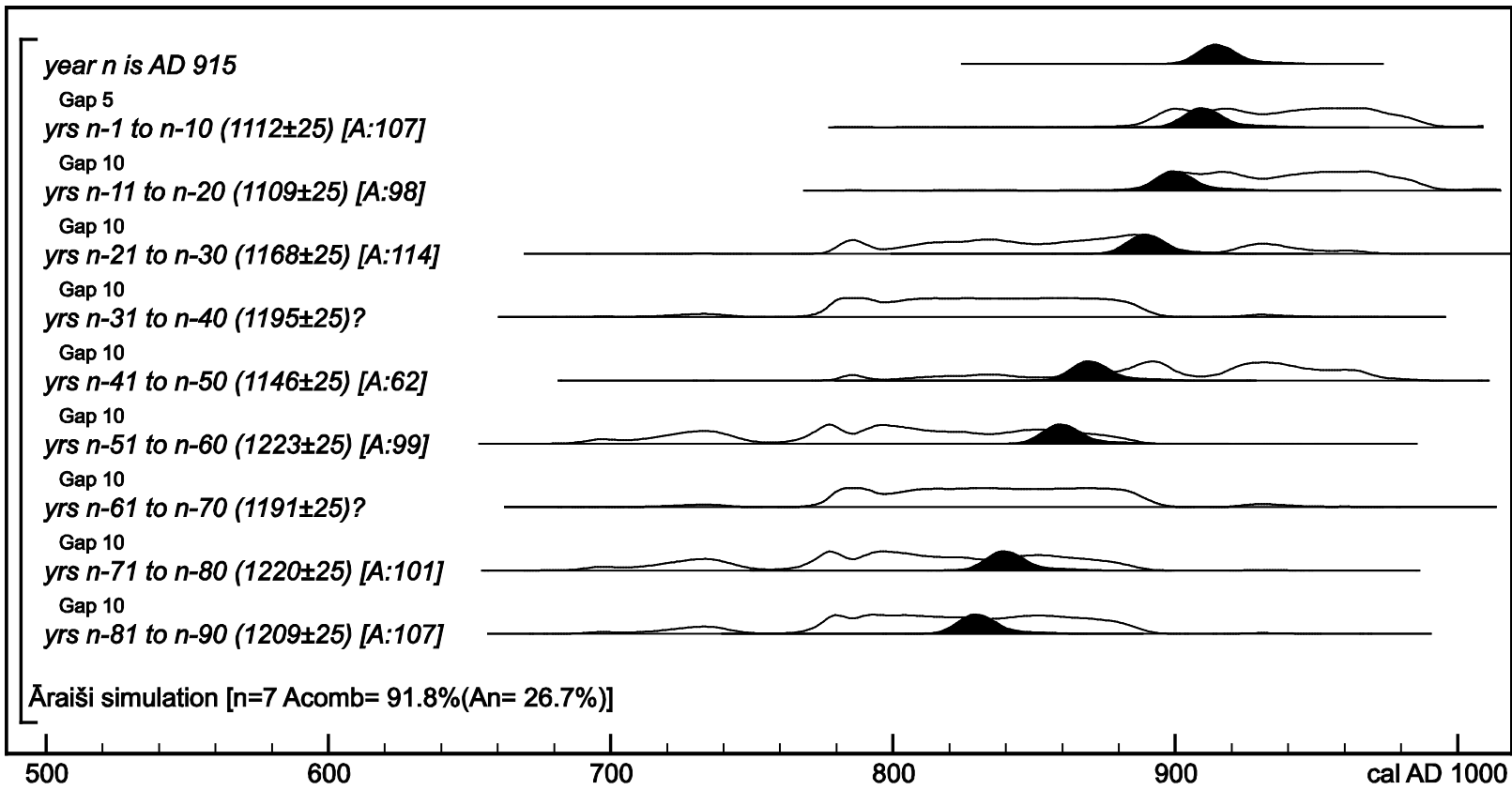

Fig. 5. Calibration and wiggle-matching of simulated ${ }^{14} \mathrm{C}$ ages, obtained using the OxCal function R_Simulate and the IntCal09 calibration data (Reimer et al., 2009), corresponding to samples whose real ages are centred on $A D 830,840,850, \ldots 910$. Distributions in outline are simple calibrations of the simulated ${ }^{14} \mathrm{C}$ ages; solid distributions are model estimates of the dates of the samples, and of the felling date (year $\mathrm{n}$, which in this simulation is $A D$ 915), based on the calibrated dates and known age differences between samples. These estimates are much more precise than the calibrated dates, and are accurate (i.e. they include the real age of the tree-rings concerned). Two samples (denoted by '?') were omitted in this case, to examine how the precision of the model estimates was affected by the number of samples dated.

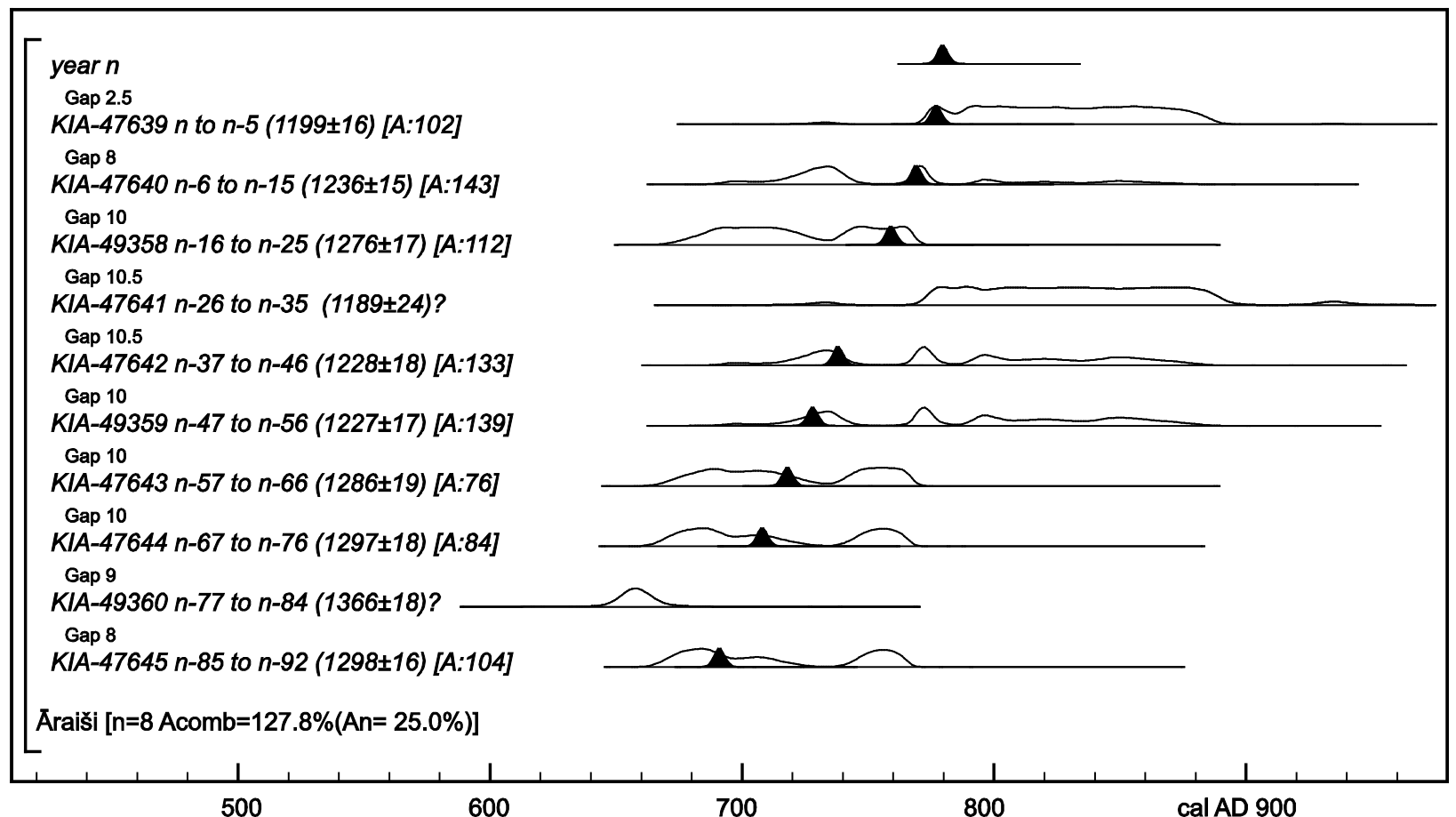

Fig. 6. Calibration and wiggle-matching of weighted mean ${ }^{14} \mathrm{C}$ ages, Āraiši timber ar173 (Table 1). Distributions in outline are simple calibrations of the ${ }^{14} \mathrm{C}$ ages; solid distributions are model estimates of the dates of the samples, and of the felling date (year $\mathrm{n}$, which is estimated to fall in AD 775784 [95\% probability] using single-year resolution [r:1]). Two samples (denoted by '?') were omitted, as explained in the text. The satisfactory individual indices of agreement $[A>60]$ and combined agreement index $\left[A_{\text {comb }}\right]$ show that the ${ }^{14} \mathrm{C}$ ages, calibrated using the IntCal13 calibration data, are consistent with the known age differences between samples. 
Table 1. Āraiš ${ }^{14} \mathrm{C}$ results. All samples consisted of untreated dry wood from a single Norway spruce (Picea abies (L.) Karst.) timber. We have used OxCal 4.2 (Bronk Ramsey, 2009) and the IntCal13 calibration data (Reimer et al., 2013) to calibrate the results. Calibrated date ranges are for the weighted mean ${ }^{14} \mathrm{C}$ age of each sample, before wiggle-matching (i.e., disregarding the relative dating given by the ring-counts).

\begin{tabular}{|c|c|c|c|c|c|}
\hline Rings & Lab code & $\begin{array}{c}\text { AMS } \\
\delta^{13} \mathrm{C}(\% 0) \\
\end{array}$ & $\begin{array}{c}\text { Corrected }{ }^{14} \mathrm{C} \\
\text { concentration }\left(\mathrm{F}^{14} \mathrm{C}\right) \\
\end{array}$ & $\begin{array}{c}\text { Conventional }{ }^{14} \mathrm{C} \text { age } \\
\text { (BP) }\end{array}$ & $\begin{array}{l}\text { Calibrated date ranges } \\
\text { (cal AD, \% probability) }\end{array}$ \\
\hline \multirow{3}{*}{$n$ to $n-5$} & \multirow{3}{*}{ KIA-47639 } & $-24.66 \pm 0.30$ & $0.8542 \pm 0.0026$ & $1265 \pm 25$ & \multirow{3}{*}{ 770-885 (95.4\%) } \\
\hline & & $-24.41 \pm 0.10$ & $0.8664 \pm 0.0022$ & $1150 \pm 20$ & \\
\hline & & weighted mean & $T=13.3^{*}$ & $1199 \pm 16$ & \\
\hline \multirow{3}{*}{$n-6$ to $n-15$} & \multirow{3}{*}{$\mathrm{KIA}-47640$} & $-24.82 \pm 0.19$ & $0.8570 \pm 0.0023$ & $1240 \pm 20$ & \multirow{3}{*}{$\begin{array}{l}690-750(54.2 \%) \\
760-780(17.4 \%) \\
790-870(23.9 \%)\end{array}$} \\
\hline & & $-25.12 \pm 0.19$ & $0.8577 \pm 0.0021$ & $1235 \pm 20$ & \\
\hline & & weighted mean & $T=0.0^{*}$ & $1236 \pm 15$ & \\
\hline \multirow{3}{*}{$n-16$ to $n-25$} & \multirow{3}{*}{ KIA-49358 } & $-24.72 \pm 0.22$ & $0.8538 \pm 0.0025$ & $1270 \pm 25$ & \multirow{3}{*}{$\begin{array}{l}675-735(56.8 \%) \\
735-770(38.6 \%)\end{array}$} \\
\hline & & $-26.19 \pm 0.23$ & $0.8525 \pm 0.0025$ & $1280 \pm 25$ & \\
\hline & & weighted mean & $\mathrm{T}=0.1^{*}$ & $1276 \pm 17$ & \\
\hline \multirow{2}{*}{$n-26$ to $n-36$} & \multirow{2}{*}{$\mathrm{KIA}-47641$} & $-24.66 \pm 0.18$ & $0.8300 \pm 0.0024$ & $1495 \pm 25$ & \multirow{2}{*}{ rejected } \\
\hline & & $-26.03 \pm 0.16$ & $0.8624 \pm 0.0025$ & $1190 \pm 25$ & \\
\hline \multirow{3}{*}{$n-37$ to $n-46$} & \multirow{3}{*}{ KIA-47642 } & $-24.91 \pm 0.11$ & $0.8584 \pm 0.0025$ & $1225 \pm 25$ & \multirow{3}{*}{$\begin{array}{l}690-750(29.6 \%) \\
760-880(65.8 \%)\end{array}$} \\
\hline & & $-25.36 \pm 0.08$ & $0.8580 \pm 0.0027$ & $1230 \pm 25$ & \\
\hline & & weighted mean & $\mathrm{T}=0.0^{*}$ & $1228 \pm 18$ & \\
\hline \multirow{3}{*}{$n-47$ to $n-56$} & \multirow{3}{*}{ KIA-49359 } & $-24.72 \pm 0.21$ & $0.8580 \pm 0.0025$ & $1230 \pm 25$ & \multirow{3}{*}{$\begin{array}{c}695-705(0.9 \%) \\
710-750(25.7 \%) \\
765-880(68.8 \%)\end{array}$} \\
\hline & & $-25.39 \pm 0.12$ & $0.8589 \pm 0.0025$ & $1220 \pm 25$ & \\
\hline & & weighted mean & $T=0.1^{*}$ & $1227 \pm 17$ & \\
\hline \multirow{3}{*}{$n-57$ to $n-66$} & \multirow{3}{*}{ KIA-47643 } & $-23.50 \pm 0.13$ & $0.8529 \pm 0.0028$ & $1280 \pm 25$ & \multirow{3}{*}{$\begin{array}{l}670-730(58.7 \%) \\
735-770(36.7 \%)\end{array}$} \\
\hline & & $-23.39 \pm 0.13$ & $0.8514 \pm 0.0028$ & $1295 \pm 25$ & \\
\hline & & weighted mean & $T=0.2^{*}$ & $1286 \pm 19$ & \\
\hline \multirow{3}{*}{$n-67$ to $n-76$} & \multirow{3}{*}{ KIA-47644 } & $-23.94 \pm 0.17$ & $0.8502 \pm 0.0025$ & $1305 \pm 25$ & \multirow{3}{*}{$\begin{array}{l}665-725(62.5 \%) \\
740-770(32.9 \%)\end{array}$} \\
\hline & & $-24.03 \pm 0.17$ & $0.8516 \pm 0.0027$ & $1290 \pm 25$ & \\
\hline & & weighted mean & $\mathrm{T}=0.1^{*}$ & $1297 \pm 18$ & \\
\hline \multirow{3}{*}{$n-77$ to $n-84$} & \multirow{3}{*}{ KIA-49360 } & $-24.34 \pm 0.28$ & $0.8443 \pm 0.0025$ & $1360 \pm 25$ & \multirow{3}{*}{ rejected } \\
\hline & & $-25.18 \pm 0.22$ & $0.8429 \pm 0.0026$ & $1375 \pm 25$ & \\
\hline & & weighted mean & $T=0.1^{*}$ & $1366 \pm 16$ & \\
\hline \multirow{3}{*}{$n-85$ to $n-92$} & \multirow{3}{*}{ KIA-47645 } & $-24.89 \pm 0.13$ & $0.8542 \pm 0.0026$ & $1265 \pm 25$ & \multirow{3}{*}{$\begin{array}{l}665-720(62.9 \%) \\
740-770(32.5 \%)\end{array}$} \\
\hline & & $-23.89 \pm 0.15$ & $0.8482 \pm 0.0022$ & $1320 \pm 20$ & \\
\hline & & weighted mean & $\mathrm{T}=3.1^{*}$ & $1298 \pm 16$ & \\
\hline
\end{tabular}

${ }^{*}$ Critical values, $v=1: T^{\prime}(5 \%)=3.8, T^{\prime}(1 \%)=6.0($ Ward and Wilson, 1978)

Age inhomogeneity appears to explain the discrepancy between the two results for KIA-47639. Following Ward and Wilson (1978), the two results are inconsistent even at the 0.01 significance level $(v=1, T=13.3$, $T(1 \%)=6.0)$; in other words, the probability of obtaining two such different results from a completely homogenous sample is less than 1 in 100 . According to the wiggle-match model, this sample probably includes the year AD 775, when single-year tree-ring samples show a sharp spike in atmospheric ${ }^{14} \mathrm{C}$ levels (Miyake et al., 2012; Usoskin et al., 2013). KIA-47639 consisted of 6 growth rings (years $n$ to $n-5$ ), but only 3 rings from the middle of the sample were actually processed, and not all the processed material was used, so it is entirely possible that the dated fractions are effectively single-year samples from just before $(1265 \pm 25 \mathrm{BP})$ and just after $(1150 \pm 20 \mathrm{BP})$ the $\mathrm{AD} 775{ }^{14} \mathrm{C}$ spike. In the model, we have used their weighted mean, $1199 \pm 16 \mathrm{BP}$, to estimate the ${ }^{14} \mathrm{C}$ age of the sample's calendrical midpoint. Our approach implies that both KIA-47639 ${ }^{14} \mathrm{C}$ ages are deemed to be accurate.

The two results for KIA-47641, on the other hand, are both problematic. Contamination before or during pre- treatment does not explain the discrepancy, because one result $(1495 \pm 25 \mathrm{BP})$ is much older than expected, while the other $(1190 \pm 25 \mathrm{BP})$ appears to be too young. It is conceivable that the younger ${ }^{14} \mathrm{C}$ age might be accurate, assuming that most of the carbon came from a small number of tree rings, but the older result appears to indicate contamination with "dead" carbon during combustion or graphitization.

KIA-49360 presents a different challenge. This sample should date to the late AD 690s, if year $n$ falls shortly after $\mathrm{AD} 775$, but its ${ }^{14} \mathrm{C}$ ages $(1360 \pm 25 \mathrm{BP}$ and $1375 \pm 25 \mathrm{BP}$ ) are both more than 2-sigma older than the expected ${ }^{14} \mathrm{C}$ age (IntCal13 includes 3 decadal samples centred on $1255 \mathrm{cal} \mathrm{BP}$, with ${ }^{14} \mathrm{C}$ ages between $1249 \pm 29$ and $1271 \pm 29$ BP). Nevertheless, the consistency in the AMS results excludes the possibility of a measurement error, and all the diagnostic data (e.g., yield, \%C, graphite weight and appearance, AMS currents, $\delta^{13} \mathrm{C}$ values) are satisfactory, as they are for the other samples in this series.

Thus the KIA-49360 results would be accepted without question, were it not for the fact that this sample was 
formed after KIA-47645 and before KIA-47644. The two KIA-49360 results are too similar to suppose that the anomalously high ${ }^{14} \mathrm{C}$ ages represent short-term fluctuations in atmospheric ${ }^{14} \mathrm{C}$ levels. A more rigorous pretreatment protocol (e.g. extracting $\alpha$-cellulose) is unlikely to resolve the KIA-49360 problem: such protocols aim to remove resin and lignin, which may contain carbon photosynthesised after the formation of the $\alpha$-cellulose in the tree-rings (Hoper et al., 1998). Even if older resin or lignin attached itself to younger tree-rings, it would need to be very old to increase a sample's ${ }^{14} \mathrm{C}$ age by $c .80{ }^{14} \mathrm{C}$ years, but the tree in question was still young when the KIA-49360 growth rings were formed. If all the samples were affected by resin or lignin transport, their ${ }^{14} \mathrm{C}$ ages would be less variable than otherwise, but the overall dating of the timber would be similar, as the carbon in resin, lignin and $\alpha$-cellulose was photosynthesised over the same period. Indeed, alternative pretreatments have been shown to have no effect on the wiggle-matched date of a conifer timber (Tyers et al., 2011).

In the absence of a plausible environmental or physiological mechanism for incorporating older carbon only in the 8 growth rings represented by KIA-49360, we may suppose that a more recent source of dead-carbon contamination affected this particular sample. FTIR spectroscopy of pretreated material from KIA-49360 gave an identical spectrum to that of pretreated material from the other samples, which is also consistent with published spectra for unconsolidated spruce wood (Crisci et al., 2010). These patterns appear to rule out contamination with a consolidant (as well as sample substitution) before or during pretreatment. Moreover, a consolidant applied before the timber was cut into sub-decadal blocks should also have affected the ${ }^{14} \mathrm{C}$ ages of the other samples. If the two dated fractions of KIA-49360 were contaminated after the pretreated material was split, however, an approximately equal amount of the contaminant must have been added to each fraction, or the two fractions would have produced inconsistent ${ }^{14} \mathrm{C}$ ages. Thus no explanation has been found for the anomalous KIA-49360 results.

\section{Comparison with previous results}

However the anomalous results for KIA-49360 are explained, the new dates mean that the Āraiši lake fortress is significantly older than previously thought. Our model (Fig. 6) dates the final ring of timber 173 to 775 784 cal AD (95\% probability). Alternative wiggle-match models, which e.g. use IntCal09, omit one or both of the KIA-47639 results, or include the results omitted in Fig. 6, always indicate a late $8^{\text {th }}$-century felling date. According to dendrochronological cross-matching, the same felling date applies to other timbers from the log platform and several Phase I buildings, while the remaining Phase I buildings are only 1-2 years later (Fig. 4). If the 3 treerings from KIA-47639 that were actually processed include the AD 775 "event" and at least one year before it, we can be even more specific: AD 775 should correspond to year $n-1, n-2$ or $n-3$, so year $n$ would be either $\mathrm{AD} 776$, 777 or 778 . Thus we believe that all the Phase I timbers were felled by AD 780 .

Previously, the platform had been dated to "AD 830" or c. AD 920-930 (see Introduction). A broader range (840-950 cal AD, $>85 \%$ probability) is obtained if we ignore the absolute dendro-dating based on visual crossmatches with timbers from Novgorod, using only the relative dating provided by the dendro-dates to wigglematch the St Petersburg ${ }^{14} \mathrm{C}$ ages to IntCall3 (Fig. 3). Provided that the timber(s) dated really came from Phase I at Āraiši, there is a clear contradiction between the Kiel and St Petersburg wiggle-matches. The St Petersburg data do not provide a true wiggle-match, however: according to the reported dendro-dating, the 4 samples span barely 40 years in total ( 29 years, if we consider only the midpoints of the samples). Three samples are successive 5year blocks, and the fourth encompasses 20 growth rings (Zaitseva and Popov 1994, table 1). Their ${ }^{14} \mathrm{C}$ ages, which fall on a plateau in the calibration curve, are not statistically significantly different $\left(T=1.9, T^{\prime}(5 \%)=7.8, v=3\right.$; Ward and Wilson, 1978). Nevertheless, however the St Petersburg results are modelled - even disregarding any relative dating information - the estimated felling date must be later than cal AD 780, and is probably not before the mid- $9^{\text {th }}$ century.

It is difficult to explain this disagreement in scientific terms. The main difference between laboratories in sample pretreatment is that St Petersburg used a benzenealcohol mix to remove resins; as discussed above, however, the presence or absence of resin cannot give systematically older or younger ${ }^{14} \mathrm{C}$ ages, because carbon in the resin was assimilated during the tree's lifetime. The St Petersburg ${ }^{14} \mathrm{C}$ results were not corrected for natural isotopic fractionation, and are therefore based on an assumed $\delta^{13} \mathrm{C}$ value of $-25 \%$. Conifer wood is often slightly enriched, but if a $1-2 \%$ higher $\delta^{13} \mathrm{C}$ value were used to correct the St Petersburg ${ }^{14} \mathrm{C}$ ages, it would only shift them $16-32{ }^{14} \mathrm{C}$ years earlier, and would barely alter their wiggle-match position.

Four other sequences reported by Zaitseva and Popov (1994) can be wiggle-matched, as a check on the accuracy of the ${ }^{14} \mathrm{C}$ ages and absolute and relative dendro-dates. The Novgorod TC-Y111-28-50 sequence is even shorter than that for Āraiši (4 samples spanning 24 dendro-years, between sample midpoints), and again, the $4{ }^{14} \mathrm{C}$ ages are not statistically significantly different. The longer sequence from Ušuri $\left(11{ }^{14} \mathrm{C}\right.$ samples spanning 65 dendroyears) shows a good fit between the Moscow dendrodates and St Petersburg ${ }^{14} \mathrm{C}$ results for the same samples (Fig. 7). At face value, this implies that the Novgorod absolute chronology may be applicable in Latvia; even if we disregard the absolute dendro-dates, the Ušuri relative dendro-dating appears to support the validity of the St Petersburg ${ }^{14} \mathrm{C}$ results (although the ${ }^{14} \mathrm{C}$-age uncertainties are still quite large, relative to the length of the sequence). On the other hand, the Novgorod sequences 


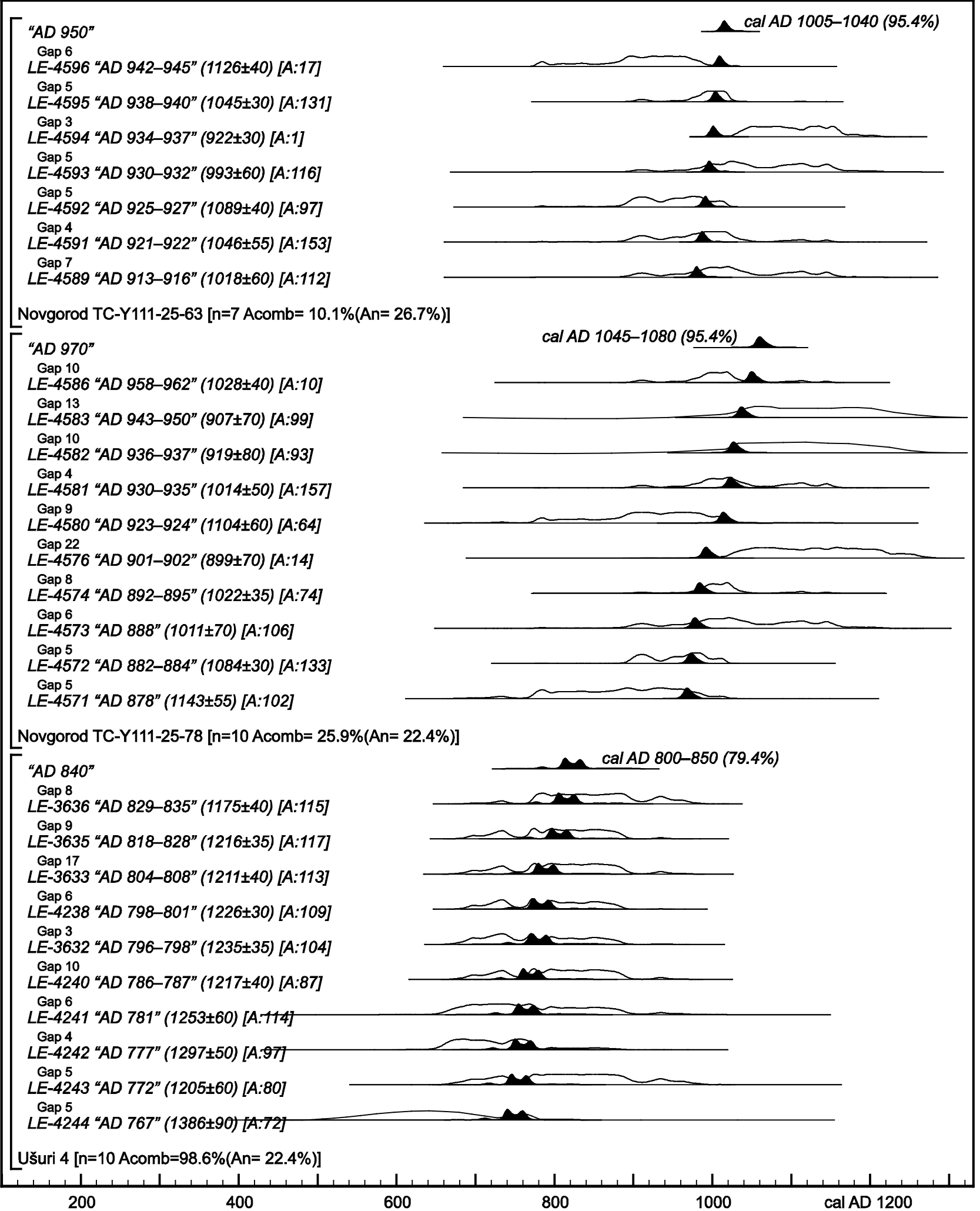

Fig. 7. Further wiggle-matches of ${ }^{14} \mathrm{C}$ ages reported by Zaitseva and Popov (1994). The format is the same as that of Fig. 3. Ušuri 4: ${ }^{14} \mathrm{C}$ ages are consistent with both the relative and absolute dendro dates reported; Novgorod TC Y111-25-78: ${ }^{14} \mathrm{C}$ ages are barely consistent with relative dendro dates, and clearly later than the absolute dendro dates; Novgorod TC Y111-25-63: ${ }^{14} \mathrm{C}$ ages are inconsistent with relative dendro dates, and are clearly later than the absolute dendro dates reported. 
TC-Y111-25-63 $\left(7{ }^{14} \mathrm{C}\right.$ samples spanning 39 dendroyears $)$ and TC-Y111-25-78 $\left(10{ }^{14} \mathrm{C}\right.$ samples spanning 82 dendro-years) are problematic; in both cases, wigglematching the ${ }^{14} \mathrm{C}$ results to IntCal13 dates the samples c. 100 years later than the dendro-dates cited (Fig. 7; cf Zaitseva and Popov 1994, table 1), and some results do not fit their relative dendro-dates. Whether these problems reflect flaws in sampling, dendrochronology or ${ }^{14} \mathrm{C}$ dating - or a combination of these - they cast some doubt on the previously reported dates for Āraiši.

Another explanation may be that the St Petersburg Āraiši samples are from a later structural phase (or another site altogether). This is not entirely unrealistic, given the time elapsed between the excavation, dendro measurement and St Petersburg ${ }^{14} \mathrm{C}$ dating, and the number of institutions involved, but even the original Phase I result from Tartu, which is not in conflict with the later $9^{\text {th }}$ earlier $10^{\text {th }}$ century date for the platform implicit in the $\mathrm{St}$ Petersburg ${ }^{14} \mathrm{C}$ dating, does not fit a felling date of $c$. AD 780. As Apals was in direct contact with the Tartu laboratory, it is unlikely that the attribution of this timber to Phase I was incorrect. However, only internal laboratory standards were used to check the accuracy and precision of ${ }^{14} \mathrm{C}$ measurements. When the first international laboratory inter-comparison was published (International Study Group, 1982), it was suggested that quoted ${ }^{14} \mathrm{C}$ errors (in comparable laboratories, dating the same wood) had to be at least doubled to obtain realistic measurement uncertainties. If the Tartu quoted ${ }^{14} \mathrm{C}$ errors are doubled, the AD 780 date becomes perfectly plausible.

\section{CONCLUSION}

The Institute of Latvian History tree-ring chronology for Phase I of the Āraiši lake fortress has been dated quite precisely, with surprising results. Our results imply that Phase I was completed by $c$. AD 780, 50-150 years earlier than previously reported. The new dates are incompatible with previous attempts to date the settlement, which raises questions about the accuracy of chronologies at sites such as Novgorod. Given the new results, ${ }^{14} \mathrm{C}$ dating of single-ring samples between years $n$ and $n-5$ should locate the AD $775{ }^{14} \mathrm{C}$ anomaly. This would absolutely date the chronology, notwithstanding the fact that we have not yet found a satisfactory dendrochronological cross-match between the relatively short Āraiši spruce chronology and absolute chronologies for pine or spruce in e.g. Scandinavia or Poland.

\section{ACKNOWLEDMENTS}

The authors would like to thank Dr Valdis Bērzinšs (Institute of Latvian History at the University of Latvia) and Dr Andrzej Rakowski and Anke Rieck (LeibnizLabor für Altersbestimmung und Isotopenforschung, Christian-Albrechts-Universität zu Kiel) for their helpful comments and suggestions.

\section{REFERENCES}

Apals J, 1998. Āraiši (Arrasch), in Lübke C and Wędyki A, Enzyklopädie zur Geschichte des östlichen Europa (6.-13. Jahrhundert) (Encyclopedia of Eastern European History (6th-13th centuries)), Greifswald: 151-152 (in German).

Apals J, 2000. Über die Entwicklung eines Blockbautyps im Ostbaltikum (On the development of a type of log cabin in the East Baltic). Archaeologia Baltica 4: 149-158 (in German).

Apals J, 2001. Ezerpilis (Lake fortresses), in Apals J, Atgāzis M, Graudonis J, Loze I, Mugurēvičs E, Vasks A and Zagorska I, Latvijas senākā vēsture: 9. g. t. pr. Kr. - 1200. g. Rīga, Latvijas vēstures institūta apgāds: $311-317$ (in Latvian)

Apals J, 2008. Äraišu arheologiskais muzejparks: celvedis (Āraiši Archaeological Museum Park: Guide). Rīga, Latvijas Nacionālais vēstures muzejs: 96 pp (in Latvian).

Apals J, 2012a. Hidroarheolog̣iskās ekspedīcijas darbs 1965. gadā (Work of an archaeological expedition in 1965), in Apals J, Araišu ezerpils. Rakstu izlase un draugu atmingas. Rīga, Latvijas vēstures institūta apgāds: 62-65 (in Latvian).

Apals J, 2012b. Hidroarheologisko pieminekḷu apzināšana 1964. gadā (Exploration of underwater archaeological monuments in 1964), in Apals J, Āraišu ezerpils. Rakstu izlase un draugu atmingas. Rīga, Latvijas vēstures institūta apgāds: 57-62 (in Latvian).

Apals J, 1983. Par Āraišu ezerpils izpēti: 1965.-1969., 1975.-1979. gads (On the investigation of the Äraiši lake fortress: 1965-1969, 1975-1979). Jaunā Gaita 145: 26-33 (in Latvian).

Bronk Ramsey C, 1995. Radiocarbon calibration and analysis of stratigraphy: The OxCal program. Radiocarbon 37: 425-430.

Bronk Ramsey C, van der Plicht J and Weninger B, 2001. 'Wiggle matching' radiocarbon dates. Radiocarbon 43: 381-389.

Bronk Ramsey C, 2009. Bayesian analysis of radiocarbon dates. Radiocarbon 51: 337-360.

Chernyh NB, 1987. Dendrohronologicheskie shkaly Vostochnoj Evropy vtoroj poloviny $1-2$ tys. n.e. ( 25 - letiyu laboratorii estestvennonauchnyh metodov instituta arheologii AN SSSR) (Dendroscales of East Europe covering the second half of the 1st millennium and the 2nd millennium AD (25 years of the Natural Sciences Methods Laboratory of the Institute of Archaeology AS USSR)). In: Bitvinskas T, ed., Vremennye $i$ prostranstvennye izmeneniya klimata $i$ godichnye kol'tsa derev'ev, III. Kaunas, Institut botaniki AN Litovskoj SSR: 90-98 (in Russian).

Chernyh NB, 1996. Dendrohronologiya i arheologiya (Dendrochronology and Archaeology), Moscow, NOX: 215pp (in Russian).

Cook ER and Holmes RL, 1986. Users manual for program Arstan. In: Holmes R L, Adams R K and Fritts H C, eds., Tree-ring chronologies of western North America: California, eastern Oregon and northern Great Basin. Tucson, Laboratory of Tree-Ring Research, University of Arizona. Chronology Series 6: 50-65.

Crisci GM, La Russa MF, Malagodi M and Ruffolo SA, 2010. Consolidating properties of Regalrez 1126 and Paraloid B72 applied to wood. Journal of Cultural Heritage 11(3): 304-308, DOI 10.1016/j.culher.2009.12.001.

Grissino-Mayer HD, 2001. Evaluating crossdating accuracy: a manual and tutorial for the computer program COFECHA. Tree-Ring Research 57: 205-221.

Holmes RL, 1983. Computer-assisted quality control in tree-ring dating and measurement. Tree-Ring Bulletin 44: 69-75.

Hoper S, McCormac F, Hogg A, Higham T and Head M, 1998. Evaluation of wood pretreatments on oak and cedar. Radiocarbon 40: 4550 .

International Study Group, 1982. An inter-laboratory comparison of radiocarbon measurements in tree-rings. Nature 298(5875): 619 623, DOI 10.1038/298619a0.

McCormac FG, Bayliss A, Baillie, MGL and Brown DM, 2004. Radiocarbon calibration in the Anglo-Saxon period: AD 495-725. Radiocarbon 46: 1123-1125.

McCormac FG, Bayliss A, Brown DM, Reimer PJ and Thompson MM, 2008. Extended radiocarbon calibration in the Anglo-Saxon period, AD 395-485 and AD 735-805. Radiocarbon 50: 11-17. 
Miyake F, Nagaya K, Masuda K and Nakamura T, 2012. A signature of cosmic-ray increase in AD 774-775 from tree rings in Japan. $\mathrm{Na}$ ture 486(7402): 240-242, DOI 10.1038/nature11123.

Nadeau M-J, Grootes PM, Schleicher M, Hasselberg P, Rieck A and Bitterling M, 1998. Sample throughput and data quality at the Leibniz-Labor AMS facility. Radiocarbon 40: 239-245.

Punning JM, Liiva A and Ilves E, 1968. Tartu radiocarbon dates III. Radiocarbon 10: 379-383.

Reimer PJ, Baillie MGL, Bard E, Bayliss A, Beck JW, Blackwell PG, Bronk Ramsey C, Buck CE, Burr GS, Edwards RL, Friedrich M, Grootes PM, Guilderson TP, Hajdas I, Heaton TJ, Hogg AG, Hughen KA, Kaiser KF, Kromer B, McCormac G, Manning S, Reimer RW, Remmele S, Richards DA, Southon JR, Talamo S, Taylor FW, Turney CSM, van der Plicht J and Weyhenmeyer CE, 2009. INTCAL09 and MARINE09 radiocarbon age calibration curves, 0-50,000 years cal BP. Radiocarbon 51: 1111-1150.

Reimer PJ, Bard E, Bayliss A, Beck JW, Blackwell PG, Bronk Ramsey C, Grootes PM, Guilderson TP, Haflidason H, Hajdas I, Hatte C, Heaton TJ, Hoffmann DL, Hogg AG, Hughen KA, Kaiser KF, Kromer B, Manning SW, Niu M, Reimer RW, Richards DA, Scott EM, Southon JR, Staff RA, Turney CSM and van der Plicht J, 2013. IntCal13 and Marine13 radiocarbon age calibration curves
0-50,000 years cal BP. Radiocarbon 55: 1869-1887.

Stuiver M, Reimer PJ, Bard E, Beck JW, Burr GS, Hughen KA, Kromer B, McCormac G, van der Plicht J and Spurk M, 1998. INTCAL98 radiocarbon age calibration, $24,000-0$ cal BP. Radiocarbon 40: 1041-1083.

Tyers C, Sidell J, van der Plicht J, Marshall P, Cook G, Bronk Ramsey $\mathrm{C}$ and Bayliss A, 2011. Wiggle-matching using known-age pine from Jermyn Street, London. Radiocarbon 51: 385-396.

Usoskin IG, Kromer B, Ludlow F, Beer J, Friedrich M, Kovaltsov GA, Solanki SK and Wacker L, 2013. The AD775 cosmic event revisited: the Sun is to blame. Astronomy \& Astrophysics 552: L3, DOI 10.1051/0004-6361/201321080.

Ward GK and Wilson SR, 1978. Procedures for comparing and combining radiocarbon age determinations: a critique. Archaeometry 20(1): 19-31, DOI 10.1111/j.1475-4754.1978.tb00208.x.

Zaitseva GI and Popov SG, 1994. Radiocarbon dating sites of northwest Russia and Latvia. Radiocarbon 36: 377-389.

Zunde M, 2000. Par Āraišu ezerpils dendrohronoloǵisko datēšanu (On the dendrochronological dating of Āraiši lake fortress). In: Arheologs Dr. hist., Dr. hist. h.c. Jānis Apals: Bibliogrāfija, darbabiedru veltījumi 70 gadu jubilejā. Rīga, Latvijas vēstures institūta apgāds: 144-157 (in Latvian). 